\title{
Effect of Holding Solutions on the Water Relations in Vase Life of Cut Carnation cv. Kiro
}

\author{
P. Pranuthi, T. Suseela, D. V. Swami*, D. R. Salomi Suneetha and V. Sudha Vani \\ Department of Floriculture and Landscape Architecture, Dr. Y.S.R. Horticultural University, \\ Venkataramannagudem, West Godavari dist. (Andhra Pradesh), India \\ *Corresponding author
}

A B S T R A C T

\section{Keywords}

Carnation, Holding

solution, Water uptake,

Transpirational loss of

water, Water balance,

Fresh weight change

Article Info

Accepted:

10 July 2018

Available Online:

10 August 2018
An investigation was carried out to study the effect of different holding solution combinations on vase life of cut carnation cv. Kiro. The flowers were kept under common holding solution (sucrose 4\% + 8-HQS 200 ppm) along with $\mathrm{GA}_{3}$ at $25 \mathrm{ppm}$ recorded significantly highest water uptake on $6^{\text {th }}$ day (33.83 $\mathrm{g}$ flower $\left.^{-1}\right)$ the highest transpirational loss of water $(32.16 \mathrm{~g}$ flower $^{-1}$ ) and highest fresh weight change of flower (152.38 $\mathrm{g} \mathrm{flower}^{-1}$ ) which have extended the vase life period of carnation flower cv. Kiro.

\section{Introduction}

Carnation (Dianthus caryophyllus L.) is an important cut flower in the world. Carnation is a climatric flower that is highly sensitive to ethylene (Pun et al., 1999). Due to high perishability, cut flowers are vulnerable to large post-harvest losses upto 50 per cent of the farm value (Singh et al., 2007). Carnations are more susceptible to mechanical and physical damages and microbial infections by diseases and pests during and after harvest. Floral preservatives affect the quality of cut flowers by extending the vase life, increasing flower size and maintaining the colour of leaves and petals.
The vase life of cut flowers and foliage is often shortened by vascular occlusions that constrict vase solutions supply, reduction in stem conductivity is typically caused by blockage of cut stem ends and xylem conduits by microbes, physiological plugging and water columns in xylem vessels by cavitations and air emboli.

Cut flower and foliage longevity can be greatly affected by chemical composition of the vase solution. A broad range of biocides has been suggested to prevent the proliferation of microorganisms in vase solutions. However, their assumed antimicrobial action may be confounded by their other 
physicochemical effects (Edrisi et al., 2012). Water relations plays a critical role in the postharvest life of cut flowers, water imbalance within the cut flower resulting in wilting, one of the major causes for termination of vase life (Halevy and Mayak, 1981).

\section{Materials and Methods}

The experiment was held in laboratory of Floriculture and Landscape Architecture, College of Horticulture, Dr. Y.S.R. Horticultural University, Venkataramannagudem, West Godavari dist (A.P), during year 2017-18. Experiment was laid out in completely randomised design. Sucrose $4 \%+8$-HQS $200 \mathrm{ppm}$ was used as common holding solution. There are 11 treatments, $\mathrm{T}_{1}$ : holding solution $+\mathrm{GA}_{3} 25$ ppm, $\mathrm{T}_{2}$ : holding solution $+\mathrm{GA}_{3} 50 \mathrm{ppm}, \mathrm{T}_{3}$ : holding solution + BA $25 \mathrm{ppm}, \mathrm{T}_{4}$ : holding solution + BA $50 \mathrm{ppm}, \mathrm{T}_{5}$ : holding solution + $\mathrm{Al}_{2}\left(\mathrm{SO}_{4}\right)_{3} 150 \mathrm{ppm}, \mathrm{T}_{6}$ : holding solution $+\mathrm{Al}_{2}$ $\left(\mathrm{SO}_{4}\right)_{3} 300 \mathrm{ppm}, \mathrm{T}_{7}$ : holding solution + STS $0.25 \mathrm{mM}, \mathrm{T}_{8}$ : holding solution + STS 0.50 $\mathrm{mM}, \mathrm{T}_{9}$ : holding solution + Salicylic acid 25 ppm, $\mathrm{T}_{10}$ : holding solution + Salicylic acid 50 ppm, $\mathrm{T}_{11}$ : control (only holding solution). All the treatments are replicated thrice at $25 \pm 2^{\circ} \mathrm{C}$ ambient room temperature, 45-55 per cent relative humidity $\mathrm{RH}$ and $40 \mathrm{~W}$ cool white florescent tubes to maintain 12 hours photoperiod. In each conical flask, 6 flowers were placed in each $500 \mathrm{ml}$ conical flasks 300 $\mathrm{ml}$ of holding solution. Observations were recorded changes on water uptake, transpirational loss of water, water balance, fresh weight change and vase life.

\section{Results and Discussion}

Carnation cut flowers cv. Kiro kept under different holding solution differed significantly on water uptake, among all the treatments the flowers kept in $\left(T_{1}\right)$ holding solution (sucrose 4\% + 8-HQS 200 ppm) along with $\mathrm{GA}_{3}$ at $25 \mathrm{ppm}$ recorded the highest water uptake $\left(30.28 \mathrm{~g}\right.$ flower $\left.^{-1}\right)$ from $2^{\text {nd }}$ day to $10^{\text {th }}$ day ( $28.67 \mathrm{~g}$ flower $\left.{ }^{-1}\right)$ of vase life period while the lowest water uptake $\left(19.33 \mathrm{~g} \mathrm{flower}^{-1}\right)$ was recorded by control $\left(\mathrm{T}_{11}\right)$ only holding solution though the vase life period (Table 1). Improved water uptake might be due to the combined effect of holding solution (sucrose 4\% + 8-HQS 200 ppm) with $\mathrm{GA}_{3}$. Sucrose is a source of energy and good respiratory substrate for the maintenance of osmotic potential in flowers and improved the ability of the tissue to absorb water, hence maintain turgidity. Similar results were also reported by Lol et al., (1990) in gladiolus, Reddy and Singh (1996) and Bhaskar et al., (1999) in tuberose.

The 8-HQS has germicidal and chelating properties might have reduced the stem blockage and maintained the water conductivity in accordance with Reddy et al., (1995) in tuberose. $\mathrm{GA}_{3}$ treated flowers had continuous water uptake this might be due to hydrolysis of polysaccharides and starch into glucose and fructose which decreased the water potential in stem and flower. These results are agreed with Nowak and Mynett (1985) in Lilium and Karimi (2007) in lily.

The transpirational loss of water was significantly highest $\left(28.46 \mathrm{~g}^{\text {flower }}{ }^{-1}\right)$ from $2^{\text {nd }}$ day to $10^{\text {th }}$ day $\left(27.86 \mathrm{~g}\right.$ flower $\left.{ }^{-1}\right)$ with flowers kept in $\left(\mathrm{T}_{1}\right)$ holding solution (sucrose $4 \%+8-\mathrm{HQS} 200 \mathrm{ppm}$ ) along with $\mathrm{GA}_{3}$ at 25 $\mathrm{ppm}$, while the lowest transpirational loss of water $\left(18.53 \mathrm{~g}\right.$ flower $\left.^{-1}\right)$ throughout the vase life period was recorded by control $\left(\mathrm{T}_{11}\right)$.

When the amount of transpiration exceeds absorption, a water deficit and wilting develops. Gibberellic acid increased the water uptake and reduced the transpiration. Phytohormones have been implicated in the regulation of flower senescence (Halevy and Mayak, 1981). 
Table.1 Effect of different holding solutions on water uptake (g/flower) and transpirational loss of water (g/flower) during vase life of cut carnation cv. Kiro

\begin{tabular}{|c|c|c|c|c|c|c|c|c|c|c|}
\hline \multirow[t]{3}{*}{ Treatments } & \multicolumn{10}{|c|}{ Time period (days) } \\
\hline & \multicolumn{5}{|c|}{ Water uptake (g/flower) } & \multicolumn{5}{|c|}{ Transpirational loss of water (g/flower) } \\
\hline & 2 & 4 & 6 & 8 & 10 & 2 & 4 & 6 & 8 & 10 \\
\hline T/1-Holding solution + GA 3 @ 25ppm & 30.28 & 32.19 & 33.83 & 31.74 & 28.67 & 28.46 & 29.77 & 32.16 & 29.12 & 27.86 \\
\hline T2-Holding solution + GA 3 @ 50ppm & 28.62 & 30.82 & 31.56 & 29.93 & 27.89 & 27.52 & 28.65 & 31.06 & 27.86 & 25.42 \\
\hline T3:-Holding solution + BA @ 25ppm & 26.95 & 28.91 & 29.55 & 27.84 & 25.49 & 25.64 & 27.53 & 28.42 & 26.73 & 24.86 \\
\hline T4-Holding solution + BA @ 50ppm & 25.21 & 27.85 & 28.73 & 26.67 & 24.38 & 24.59 & 25.94 & 27.13 & 24.91 & 22.74 \\
\hline $\begin{array}{l}\mathrm{T}_{5^{-}} \text {Holding solution }+\mathrm{Al}_{2}\left(\mathrm{SO}_{4}\right)_{3} @ \\
\text { 150ppm }\end{array}$ & 24.94 & 26.95 & 27.78 & 25.81 & 23.6 & 23.90 & 25.83 & 27.10 & 24.89 & 22.92 \\
\hline $\begin{array}{l}\mathrm{T}_{6}-\text { Holding solution }+\mathrm{Al}_{2}\left(\mathrm{SO}_{4}\right)_{3} @ \\
\text { 300ppm }\end{array}$ & 25.15 & 27.13 & 28.31 & 26.17 & 23.94 & 24.25 & 26.74 & 27.62 & 25.65 & 23.19 \\
\hline $\begin{array}{l}\text { T } \text { - Holding solution + STS @ } 0.25 \\
\text { mM }\end{array}$ & 23.44 & 25.72 & 26.29 & 24.45 & 22.53 & 22.76 & 24.72 & 25.46 & 23.63 & 21.85 \\
\hline $\begin{array}{l}\text { T }{ }_{8^{-}} \text {Holding solution + STS @ } 0.50 \\
\text { mM }\end{array}$ & 24.58 & 26.81 & 27.42 & 25.62 & 23.49 & 23.62 & 25.53 & 26.37 & 24.56 & 22.64 \\
\hline $\begin{array}{l}\text { T9:Holding solution + Salicylic acid } \\
\text { @ 25ppm }\end{array}$ & 20.92 & 23.14 & 23.86 & 22.29 & 18.04 & 19.87 & 20.67 & 22.71 & 19.82 & 17.56 \\
\hline $\begin{array}{l}\text { T10: Holding solution + Salicylic acid } \\
\text { @ 50ppm }\end{array}$ & 22.68 & 24.53 & 24.94 & 23.47 & 18.89 & 20.87 & 22.42 & 23.54 & 21.45 & 18.20 \\
\hline $\mathrm{T}_{11}$ : Control (only holding solution) & 19.33 & 20.95 & 18.22 & 15.07 & - & 18.53 & 20.07 & 17.80 & 14.47 & - \\
\hline Mean & 24.72 & 26.81 & 27.31 & 26.27 & 23.81 & 23.63 & 25.26 & 26.30 & 23.91 & 20.65 \\
\hline SE d & 0.625 & 0.569 & 0.610 & 0.628 & 0.494 & 0.553 & 0.517 & 0.723 & 0.534 & 0.451 \\
\hline C.D at $5 \%$ & 1.306 & 1.187 & 1.274 & 1.310 & 1.031 & 1.155 & 1.079 & 1.509 & 1.114 & 0.941 \\
\hline
\end{tabular}


Table.2 Effect of different holding solutions on water balance (g/flower) and fresh weight change (g/flower) during vase life of cut carnation cv. Kiro

\begin{tabular}{|c|c|c|c|c|c|c|c|c|c|c|}
\hline \multirow[t]{3}{*}{ Treatments } & \multicolumn{10}{|c|}{ Time period (days) } \\
\hline & \multicolumn{5}{|c|}{ Water balance (g/flower) } & \multicolumn{5}{|c|}{ Fresh weight change (g/flower) } \\
\hline & 2 & 4 & 6 & 8 & 10 & 2 & 4 & 6 & 8 & 10 \\
\hline T$_{1}$-Holding solution + GA 3 @ 25ppm & 8.96 & 7.52 & 7.07 & 6.75 & 6.28 & 129.20 & 137.32 & 152.38 & 138.80 & 122.56 \\
\hline $\mathrm{T}_{2}$-Holding solution + GA 3 @ 50ppm & 8.16 & 7.02 & 6.83 & 6.14 & 5.92 & 121.52 & 130.50 & 141.26 & 126.71 & 115.80 \\
\hline T3:-Holding solution + BA @ 25ppm & 7.69 & 6.94 & 6.15 & 5.73 & 5.34 & 120.75 & 126.63 & 130.81 & 122.49 & 114.65 \\
\hline T4-Holding solution + BA @ 50ppm & 7.27 & 6.07 & 5.75 & 5.17 & 4.85 & 118.47 & 123.46 & 126.22 & 119.75 & 109.24 \\
\hline $\begin{array}{l}\mathrm{T}_{5^{-}} \text {Holding solution + } \mathrm{Al}_{2}\left(\mathrm{SO}_{4}\right)_{3} @ \\
\text { 150ppm }\end{array}$ & 6.80 & 5.85 & 5.00 & 4.35 & 4.06 & 115.01 & 117.47 & 120.48 & 115.34 & 112.23 \\
\hline $\begin{array}{l}\mathrm{T}_{6} \text { Holding solution }+\mathrm{Al}_{2}\left(\mathrm{SO}_{4}\right)_{3} @ \\
\text { 300ppm }\end{array}$ & 6.84 & 5.94 & 5.10 & 4.72 & 4.23 & 115.62 & 118.78 & 123.56 & 116.45 & 111.80 \\
\hline $\begin{array}{l}\text { T }{ }_{7-} \text { Holding solution + STS @ } 0.25 \\
\mathrm{mM}\end{array}$ & 5.89 & 5.05 & 4.45 & 3.80 & 3.14 & 112.35 & 114.66 & 117.81 & 109.86 & 98.58 \\
\hline $\begin{array}{l}\mathrm{T}_{8^{-}} \text {Holding solution + STS @ } 0.50 \\
\mathrm{mM}\end{array}$ & 6.75 & 5.74 & 4.90 & 4.22 & 3.95 & 114.71 & 116.50 & 119.65 & 114.26 & 108.71 \\
\hline $\begin{array}{l}\text { T9:Holding solution + Salicylic acid } \\
\text { @ 25ppm }\end{array}$ & 5.12 & 4.79 & 3.98 & 3.23 & 2.49 & 107.35 & 109.82 & 104.81 & 99.45 & 92.37 \\
\hline $\begin{array}{l}\text { T10: Holding solution + Salicylic acid } \\
\text { @ 50ppm }\end{array}$ & 5.68 & 5.11 & 4.21 & 3.97 & 3.14 & 110.33 & 112.74 & 109.40 & 103.92 & 96.58 \\
\hline $\mathrm{T}_{11}$ : Control (only holding solution) & 4.59 & 4.13 & 3.09 & 2.47 & - & 103.90 & 105.60 & 101.22 & 90.56 & - \\
\hline Mean & 6.70 & 5.83 & 5.13 & 4.595 & 3.94 & 115.35 & 119.37 & 124.25 & 114.93 & 98.84 \\
\hline SE d & 0.138 & 0.123 & 0.106 & 0.068 & 0.064 & 1.999 & 1.864 & 1.96 & 2.450 & 2.314 \\
\hline C.D at $5 \%$ & 0.288 & 0.259 & 0.221 & 0.143 & 0.134 & 4.172 & 3.889 & 4.089 & 5.112 & 4.828 \\
\hline
\end{tabular}


The water balance differed significantly among the treatments, among all the treatments, flowers kept in $\left(\mathrm{T}_{1}\right)$ holding solution (sucrose 4\% + 8-HQS $200 \mathrm{ppm}$ ) along with $\mathrm{GA}_{3}$ at $25 \mathrm{ppm}$ recorded the highest water balance (8.96 $\left.\mathrm{g}_{\text {flower }}^{-1}\right)$ through the vase life period while the lowest water balance $\left(4.59 \mathrm{~g}\right.$ flower $\left.^{-1}\right)$ was recorded by control $\left(\mathrm{T}_{11}\right)$ only holding solution (Table 2). Improved water balance might be due to the combined effect of holding solution (sucrose 4\% +8-HQS $200 \mathrm{ppm}$ ) with $\mathrm{GA}_{3}$. Water balance is a major factor influencing the quality and longevity of cut flowers. The increased water balance is due to increased water uptake and with decreased loss of water. The physiological efficiency of $\mathrm{GA}_{3}$ could maintain the positive water balance. Gibberellic acid further promoted dry matter (starch) hydrolysis into reducing sugars in the stem and flower heads, leading to enhanced vase life and quality of cut flowers via improved water balance. 8-HQS plays an important role in improving the water balance of cut freesia by preventing the growth of microorganisms in xylem and thus maintained water uptake by flower stems (Kwon and Kim, 2000). Sucrose helps in improving the water balance of cut flowers by affecting the osmotic potential of cut flowers and the water holding capacity of the tissues allowing less water to be transpired (Halevy et al., 1978).

The fresh weight was significantly highest $\left(129.20 \mathrm{~g} \mathrm{flower}^{-1}\right)$ on $2^{\text {nd }}$ day to $10^{\text {th }}$ day (122.56 $\mathrm{g}$ flower $\left.{ }^{-1}\right)$ with flowers kept in $\left(\mathrm{T}_{1}\right)$ holding solution (sucrose $4 \%+8$-HQS 200 ppm) along with $\mathrm{GA}_{3}$ at $25 \mathrm{ppm}$ while the lowest fresh weight change (103.90 g flower $\left.{ }^{1}\right)$ was recorded by control $\left(T_{11}\right)$ only holding solution (Table 2). The gain in fresh weight change was due to the synergistic effect of holding solution (sucrose 4\% + 8-HQS 200 ppm) along with $\mathrm{GA}_{3}$ might be due to $\mathrm{GA}_{3}$ increased water relations in the floral tissue by inducing stomatal closure in the leaves might have led to an increased metabolic activity without loss of quality. The combined effect of sucrose and 8-HQS might have improved the water retention of the flower contributed high fresh weight change. Similar results were reported by Jitendra kumar and Daljeet Singh (2004), Sagar et al., (2005) in tuberose.

\section{References}

Bhaskar, V.V., Rao, P.V. and Reddy, Y.N. 1999. Effect of minerals on the postharvest vase life of cut tuberose (Polyanthus tuberose L.) cv. Double. Indian Journal of Horticulture. 56(4): 368-374.

Edrisi, B., Sadrpoor, A. and Saffari, V. R. 2012. Effects of chemicals on vase life of cut Carnation (Dianthus caryophyllus L. 'Delphi') and microorganism's population in solution. Journal of Ornamental and Horticultural Plants. 2(1): 1-11.

Halevy, A.H. and Mayak, S. 1981. Senescence and postharvest physiology of cut flowers. Part I. In: Horticultural Reviews. Vol 2, AVI Publishing Westport, conn. 59-143.

Halevy, A.H., Tbyrne, G., Konfranet, A.M., Farnham, D.S., Thompson, J.F. and Hardenburg, R.E. 1978. Evaluation of postharvest handling methods for transcontinental truck shipments of cut carnations, chrysanthemums and roses. Journal of American Society of Horticultural Sciences. 103:151-155.

Jitendra Kumar and Daljeet Singh. 2004. Postharvest life of tuberose cultivar pearl double spike as affected by GA, NAA and sucrose. Journal of Ornamental Horticulture. 7(2): 188191.

Karimi, M. 2007. Effects of temperature and chemical treatments on the longevity of 
cut flowers lily. Master's thesis, Faculty of Agriculture, University of Guilan.

Kwon, H. and Kim, K. 2000. Inhibition of lipoxygenase activity and microorganism's growth in cut freesia by pulsing treatment. Journal of Korean Society of Horticultural Sciences. 41(2): 135-138.

Lol, S. D., Shah, A. and Pant, C.C. 1990. Effect of certain chemical substances on vase life and quality of gladiolus cv. Silver Horn, Prog. Hort., 89: 726-729.

Nowak, J. and Mynett, K.1985. The effect of growth regulators on post-harvest characteristics of cut lilium prima in florescences. Acta Horticulture 167: 109-116.

Pun, U. K., Rowe, R., Rowarth, J. S., Barnes, M. F., Dawson, C. O. and Heyes, J. A. 1999. Short communication Influence of ethanol on climacteric senescence in five cultivars of carnation. N.Z.J. Crop Horticultural Science. 21: 69-77.
Reddy, B. S. and Singh, K. 1996. Effect of aluminium sulphate and sucrose on vase life of tuberose. Journal of Maharashtra Agricultural Universities. 21: 201-213.

Reddy, B. S., Singh, K. and Singh, A. 1995. Effect of sucrose, citric acid and hydrox-quinoline on the postharvest physiology of tuberose cv. Single. Advances in Agriculture Research in India. 3(10): 161-167.

Sagar, N. N., Kawarkha, V. J., Manisha, D. and Lokhande, B. S. 2005. Effect of pre planting growth regulator treatments of bulbs on growth and flowering of tuberose (Polianthes tuberosa L.). The Orissa Journal of Horticulture. 33 (1): 156-159.

Singh, A., Dhaduk, B. K. and Desai, J. R. 2007. Postharvest technology and value addition in cut flowers. Floriculture today, September: 40-52.

\section{How to cite this article:}

Pranuthi, P., T. Suseela, D.V. Swami, D.R. Salomi Suneetha and Sudha Vani, V. 2018. Effect of Holding Solutions on the Water Relations in Vase Life of Cut Carnation cv. Kiro. Int.J.Curr.Microbiol.App.Sci. 7(08): 1371-1376. doi: https://doi.org/10.20546/ijcmas.2018.708.156 